\title{
Molecular characterization of triple negative breast cancer formaldehyde-fixed paraffin-embedded samples by data-independent acquisition proteomics
}

\author{
Silvia García-Adrián ${ }^{1 \pi}$, Lucía Trilla-Fuertes ${ }^{2 \pi}$, Angelo Gámez-Pozo ${ }^{3}$, Cristina Chiva ${ }^{4,5}$, Rocío \\ López-Vacas³ ${ }^{3}$ Elena López-Camacho², Guillermo Prado-Vázquez², Andrea Zapater-Moros², \\ María I. Lumbreras-Herrera², David Hardisson ${ }^{6,7,8}$, Laura Yébenes ${ }^{6}$, Pilar Zamora ${ }^{7,9,10}$, Eduard \\ Sabidó ${ }^{4,5}$, Juan Ángel Fresno Vara ${ }^{3,7^{*}}$, Enrique Espinosa ${ }^{7,9,10^{*}}$ \\ ${ }^{1}$ Medical Oncology Service, Hospital Universitario de Móstoles, Madrid, Spain \\ ${ }^{2}$ Biomedica Molecular Medicine SL, Madrid, Spain \\ ${ }^{3}$ Molecular Oncology \& Pathology Lab, Institute of Medical and Molecular Genetics-INGEMM, \\ La Paz University Hospital-IdiPAZ, Madrid, Spain \\ ${ }^{4}$ Proteomics Unit, Center for Genomics Regulation, Barcelona Institute of Science and \\ Technology (BIST), Barcelona, Spain \\ ${ }^{5}$ Proteomics Unit, Universitat Pompeu Fabra, Barcelona, Spain \\ ${ }^{6}$ Molecular Pathology and Therapeutic Targets Group, La Paz University Hospital (IdiPAZ) \\ ${ }^{7}$ Biomedical Research Networking Center on Oncology-CIBERONC, ISCIII, Madrid, Spain \\ ${ }^{8}$ Faculty of Medicine, Universidad Autónoma de Madrid, Madrid, Spain \\ ${ }^{9}$ Medical Oncology Service, La Paz University Hospital-IdiPAZ, Madrid, Spain \\ ${ }^{10}$ Cátedra UAM-Amgen, Universidad Autónoma de Madrid, Madrid, Spain \\ " These authors contributed equally to this work \\ "Corresponding authors: JAFV juanangel.fresno@salud.madrid.org; EE \\ eespinosa00@hotmail.com
}


bioRxiv preprint doi: https://doi.org/10.1101/2020.09.21.306654; this version posted September 24, 2020. The copyright holder for this preprint (which was not certified by peer review) is the author/funder. All rights reserved. No reuse allowed without permission.

Characterization of triple negative breast cancer by DIA

Running title: Characterization of triple negative breast cancer by DIA

\section{Abbreviations:}

AGC: auto-gain control

BIC: Bayesian information criterion

CNS: central nervous system

DDA: data-dependent acquisition

DFS: disease-free survival

DIA: data-independent acquisition

FDR: False discovery rate

FFPE: formalin-fixed paraffin-embedded

HCD: higher-energy collisional dissociation

HCL: hierarchical cluster

PGM: Probabilistic graphical model

SAM: Significance analysis of microarrays

TNBC: triple negative breast cancer 
Characterization of triple negative breast cancer by DIA

\section{Abstract}

Triple negative breast cancer (TNBC) accounts for $15-20 \%$ of all breast carcinomas and it is clinically characterized by an aggressive phenotype and bad prognosis. TNBC does not benefit from any targeted therapy, so further characterization is needed to define subgroups with potential therapeutic value. In this work, the proteomes of one hundred twenty-five formalinfixed paraffin-embedded samples from patients diagnosed with triple negative breast cancer were analyzed by mass spectrometry using data-independent acquisition. Hierarchical clustering, probabilistic graphical models and Significance Analysis of Microarrays were used to characterize molecular groups. Additionally, a predictive signature related with relapse was defined. Two molecular groups with differences in several biological processes as glycolysis, translation and immune response, were defined in this cohort, and a prognostic signature based on the abundance of proteins RBM3 and NIPSNAP1 was defined. This predictor split the population into low-risk and high-risk groups. The differential processes identified between the two molecular groups may serve to design new therapeutic strategies in the future and the prognostic signature could be useful to identify a population at high-risk of relapse that could be directed to clinical trials. 
bioRxiv preprint doi: https://doi.org/10.1101/2020.09.21.306654; this version posted September 24, 2020. The copyright holder for this preprint

(which was not certified by peer review) is the author/funder. All rights reserved. No reuse allowed without permission.

Characterization of triple negative breast cancer by DIA

\section{Introduction}

Triple negative breast cancer (TNBC) is defined by lack of expression of estrogen and progesterone receptors, as well as human epidermal growth factor receptor 2 (HER2). TNBC accounts for $15-20 \%$ of all invasive breast carcinomas. TNBC usually exhibits an aggressive behavior and is associated with high relapse and mortality rates, most relapses occurring within the first three years after diagnosis (1-4). Relapses usually affect visceral sites, such as the lung and central nervous system (CNS) (5-9). The standard treatment consists of surgery and adjuvant or neoadjuvant chemotherapy based on a combination of anthracyclines and taxanes.

TNBC is a heterogeneous disease. Genomic studies have determined the existence of molecular subtypes, (10-13) which have different clinical evolution and response to chemotherapy (14). A molecular classification of TNBC is not currently being used in clinical practice because it does not help clinicians in making treatment decisions. New and more informative prognostic biomarkers would be useful to select the most effective treatment.

In a recent publication, we have identified a proteomics-based biomarker combination to better stratify TNBC patients according to the benefits of the adjuvant chemotherapy (15). We used an initial discovery phase with a small cohort of patients $(n=26)$, followed by a validation phase of a subset of proteins using targeted proteomics in a large patient cohort $(n=114)$. In that study we defined a protein-based signature that predicted response to adjuvant chemotherapy. The protein signature consisted of the combination of proteins RAC2, RAB6A, BIEA and IPYR, and its classification performance was confirmed in publicly available transcriptomics datasets from independent cohorts. 
Characterization of triple negative breast cancer by DIA

Proteomics analyses based on data-independent acquisition (DIA) methods have shown an increased reproducibility of peptide quantification across multiple samples and have become the method of choice to quantify entire proteomes in large patient cohorts $(16,17)$. DIA methods rely on the use of several broadband isolation windows to select and fragment all detectable peptides within a sample (17) and several isolation schemes have been described to maximize specificity, sensitivity and speed (18-20). These methods have demonstrated a high quantitative accuracy and reproducibility on previous studies and they have been successfully used to characterize breast cancer subtypes using fresh-frozen tissue samples $(21,22)$.

In this study we relied on the high sensitivity and improved properties of data-independent acquisition methods (20) to analyze full proteomes in a large cohort of formalin-fixed paraffin embedded TNBC samples, to define molecular subgroups and stratify patients with TNBC into a group with high or low risk of relapse that improve current and future therapeutic strategies. 
bioRxiv preprint doi: https://doi.org/10.1101/2020.09.21.306654; this version posted September 24, 2020. The copyright holder for this preprint

(which was not certified by peer review) is the author/funder. All rights reserved. No reuse allowed without permission.

Characterization of triple negative breast cancer by DIA

\section{Experimental procedures}

\section{Experimental design and statistical rationale}

One hundred and forty-two formalin-fixed paraffin-embedded samples from patients diagnosed of triple negative breast cancer were analyzed using a DIA+ approach (20). Neither technical replicate analyses nor control normal tissue samples were necessary due to the large size of the clinical cohort, the nature of the samples and the objectives of the study. In addition, this study was focused in the molecular characterization of the disease and its evolution instead of the carcinogenesis mechanisms (in which comparing normal and tumor tissues are necessary); therefore, normal tissue was not used as a control.

Patient samples and clinical-pathological variables

A cohort of TNBC patients analyzed in a previous study was now analyzed by DIA+ proteomics $(15,20)$. A total of 136 patients diagnosed of TNBC between 1997 and 2004, and treated in daily clinical practice at two Spanish institutions (Hospital Universitario La Paz and Hospital Universitario 12 de Octubre) were identified and retrospectively analyzed. The inclusion criteria were: patients diagnosed with triple negative invasive breast carcinoma, nonmetastatic (stage I-III) disease at diagnosis, and a minimum follow-up of two years. Collected clinical variables were: TNM (based on TNM $7^{\text {th }}$ edition), histological grade, age at diagnosis, chemotherapy treatment, relapse, disease-free survival (DFS), and location of the first relapse. DFS was defined as the time from surgery of the primary tumor to local and/or distant tumor relapse. This project was approved by the Ethical Committees of Hospital Universitario La Paz and Hospital 12 de Octubre and all patients signed the corresponding informed consent.

\section{Sample processing and protein isolation}

Formalin-fixed paraffin-embedded (FFPE) samples were reviewed by an experienced pathologist and only samples with at least $50 \%$ of tumor cells were selected for the study. 
bioRxiv preprint doi: https://doi.org/10.1101/2020.09.21.306654; this version posted September 24, 2020. The copyright holder for this preprint

(which was not certified by peer review) is the author/funder. All rights reserved. No reuse allowed without permission.

Characterization of triple negative breast cancer by DIA

Proteins were isolated as described previously $(15,23)$. Briefly, FFPE sections were deparaffined in xylene and washed twice in ethanol. Protein extracts were eluted in $2 \%$ SDS and protein concentration was measured using MicroBCA Protein Assay Kit (Thermo Fisher Scientific). Peptide isolations were digested by trypsin and SDS was removed employing Detergent Removal Spin Columns (Thermo Fisher Scientific). Desalted peptides were solubilized in $0.1 \%$ formic acid and $3 \%$ acetonitrile. Isotopically labeled peptides were added to peptide mixes and used as internal standard for quantification.

\section{DIA+ data acquisition}

Peptide mixtures derived from the FFPE samples were analyzed using a DIA+ method in a LTQOrbitrap Fusion Lumos mass spectrometer (Thermo Fisher Scientific, San Jose, CA, USA) coupled to an EASY-nLC 1000 (Thermo Fisher Scientific (Proxeon), Odense, Denmark). Peptides were loaded directly onto the analytical column and separated by reversed-phase chromatography using a 50-cm column with an inner diameter of $75 \mu \mathrm{m}$, packed with $2 \mu \mathrm{m}$ C18 particles spectrometer (Thermo Scientific, San Jose, CA, USA).

Chromatographic gradients started at $95 \%$ buffer A and 5\% buffer B with a flow rate of 300 $\mathrm{nl} / \mathrm{min}$ for 5 minutes and gradually increased to $22 \%$ buffer $\mathrm{B}$ and $78 \% \mathrm{~A}$ in 109 min and then to $35 \%$ buffer $B$ and $65 \% \mathrm{~A}$ in $11 \mathrm{~min}$. After each analysis, the column was washed for $10 \mathrm{~min}$ with $10 \%$ buffer $A$ and $90 \%$ buffer B. Buffer A: $0.1 \%$ formic acid in water. Buffer B: $0.1 \%$ formic acid in acetonitrile.

The mass spectrometer was operated in positive ionization mode with an EASY-Spray nanosource with spray voltage set at $2.4 \mathrm{kV}$ and source temperature at $275^{\circ} \mathrm{C}$. The instrument was operated in data-independent acquisition mode, with a full MS scans over a mass range of $\mathrm{m} / \mathrm{z}$ 400-1,350 with detection in the Orbitrap (60K resolution) and with auto gain control (AGC) set to 200,000 . The isolation scheme used was the same as previously reported (20). A normalized collision energy of $28 \%+/-5 \%$ was used for higher-energy collisional dissociation 
Characterization of triple negative breast cancer by DIA

(HCD) fragmentation. MS2 scan range was set from 350 to 1850 m/z, with an AGC Target of 5.0e4 and a maximum injection time of $60 \mathrm{~ms}$. The maximum injection time was set to $20 \mathrm{~ms}$ per segment, making a total of a maximum injection time of 60 ms per composite window. Fragment ion spectra were acquired in the the Orbitrap mass analyzer at 30K resolution.

Digested bovine serum albumin (New England Biolabs cat \# P8108S) was analyzed between each sample to avoid sample carryover and to assure stability of the instrument and QCloud (24) has been used to control instrument longitudinal performance during the project.

Acquired raw data were transformed to mzXML file format with msconvert from the ProteoWizard suite v3.0.9393. Converted mzXML were further analyzed using DIA Umpire v2.1.2 (25) with the search engine Comet v2016.01 rev.0 with trypsin specificity, one allowed missed cleavage, and oxidation of methionine as variable modification (+15.9949), and carbamidomethylation at cysteine as fixed modification (+57.0214). Error tolerance was set at $10 \mathrm{ppm}$ for MS1 and 0.02 Da at MS2. The swissprot human protein database with reviewed entries and decoys was used as reference database (version April 2016). Peptides and proteins identifications were filtered at 1\% FDR. Peptide quantitation was based on the sum of the six most intense fragment ions. The median of all the spiked heavy peptides was used for data normalization. Protein abundances were estimated from normalized peptide abundances using the MSstats software (v3.10.6) (26). Two samples that exhibited less than 600 identified proteins were removed from the dataset for further analyses.

\section{Analyses of clinical variables}

A descriptive analysis of the clinical parameters was performed. Statistical comparisons were done using Chi-squared test and t-test. For survival analyses, Kaplan-Meier and log-rank methods were used. All these analyses were done in SPSS IBM Statistics v20.

Hierarchical cluster and Significance Analysis of Microarrays 
Characterization of triple negative breast cancer by DIA

Both hierarchical cluster ( $\mathrm{HCL}$ ) and Significance Analysis of Microarrays (SAM) were performed using MeV software (27). HCL is a non-supervised analysis that allows grouping samples by similar expression patterns. All the identified proteins were used to build an HCL based on Pearson correlation. After HCL, a SAM was used to characterize differences between groups identified by HCL. On the other hand, SAM allows establishing differential expressed proteins between groups. This analysis consists in a t-test corrected by permutations over the number of samples. False Discovery Rate (FDR) was used to determine the significance (28).

\section{Probabilistic graphical models and functional node activities}

The probabilistic graphical model (PGM) was built using grapHD package (29), R v3.2.5 and proteomics data without any a priori information. PGM are useful to analyze high-dimensional data. The analysis consists in two sequential steps: first, the searching of the spanning tree with the maximum likelihood, and, then, an edge depuration based on Bayesian Information Criterion (BIC) (30). The resulting network was divided in branches or functional nodes and, by gene ontology analyses, a main biological function for each branch was established. Gene ontology analyses were done using DAVID webtool (31) selecting "homo sapiens" as background and GOTERM-FAT, KEGG and Biocarta as categories. Functional node activity was calculated as the mean expression of these proteins that are related with the main function of each node, as previously described (32-34). Functional node activities were compared using Mann-Whitney tests.

\section{Predictor construction}

BRB Array Tool was used to correlate protein expression with tumor relapse (35). These proteins were selected according to their $p$-values $(p<0.01)$ and used to build a prognostic signature that classified patients into two groups (high- and low-risk) through a Cox regression. The predictor was internally validated using leave-one-out cross validation. 
bioRxiv preprint doi: https://doi.org/10.1101/2020.09.21.306654; this version posted September 24, 2020. The copyright holder for this preprint (which was not certified by peer review) is the author/funder. All rights reserved. No reuse allowed without permission.

Characterization of triple negative breast cancer by DIA

\section{Statistical analyses}

Statistical analyses were done in GraphPad Prism v6 and SPSS IBM Statistics v20. P-values were considered as statistically significant under 0.05 . 
Characterization of triple negative breast cancer by DIA

\section{Results}

Patient characteristics

One hundred and thirty-six patients with stage I to III TNBC were identified. One patient was excluded because no paraffin sample was available. Eight cases were excluded because they did not meet inclusion criteria (three with a follow-up under two years, four had received neoadjuvant therapy, and one had metastasis at diagnosis). Two samples were excluded due to the poor quality of the protein measurements. The final analyses included one hundred and twenty-five tumors.

Clinical characteristics are summarized in Table 1. This is an update of the clinical information included in our previous work (15). Median age was 56.8 years, $10 \%$ of the patients were younger than 40 years at diagnosis. Median follow-up was 64.6 months (1.1-257 months). Fifty-six (44.8\%) patients had a relapse. Most of the relapses occurred in women with tumors greater than $2 \mathrm{~cm}$, grade 3 and positive lymph nodes. Median follow-up of patients who did not relapse was 8.0 years $(2.0-21.4$ years $)$.

Ten (18\%) patients had a local and/or regional relapse, whereas $82 \%$ had a distant relapse (11 patients presented more than one location at first relapse) being the most frequent locations CNS and lung.

More than half of the relapses $(n=33,59 \%)$ occurred in the first two years since surgery of the primary tumor (median=20.2, range=1-135 months, median 22.8 months for local relapses and 18.6 for distant relapses) (Figure 1).

Seven patients did not receive any treatment after surgery (three of them, older than 80 years). Thirty-three patients received chemotherapy that did include neither anthracyclines nor taxanes (CMF was still widely used in the late 90s). Only six patients of those who received 
Characterization of triple negative breast cancer by DIA

CMF had a relapse (11 patients with stage I, 21 with stage II, and only one patient with stage III).

Proteomics experiments

As a first step towards the molecular characterization of TNBC tumors, we quantified the proteome of 140 formalin-fixed paraffin-embedded TNBC samples using the DIA+ acquisition method (20). This analysis enabled the quantification of 3,092 proteins, of which 1,206 proteins were consistently detected and quantified in at least $66 \%$ of the samples. Three samples were excluded from further analysis because they had significantly less quantified proteins (Figure 2). A gene ontology analysis showed that the identified proteins were mainly related with translational processes and extracellular membrane.

\section{Molecular classification}

Using an unsupervised hierarchical cluster analysis (HCL), two different molecular groups were defined (Sup Fig 1). Group 1 included 76 patients and group 2 included 49 patients. However, we did not find significant differences in disease-free survival (DFS) between both groups (Sup Fig 2).

By SAM, 439 differentially expressed abundant proteins between the two groups were identified (Figure 3). Most of these proteins were related to membrane, adhesion, translation, glycolysis, and mitochondria. The main functions of the proteins more abundant in Group 2 were focal adhesion and membrane whereas those proteins predominant in Group 1 were related to mRNA translation and splicing, antigen presentation and T cells, focal adhesion and the anaphase process.

Functional proteomics 
Characterization of triple negative breast cancer by DIA

A probabilistic graphical model (PGM) was built using the 1,206 quantified proteins to study protein functional relationships. The resulting network was divided into 10 functional nodes by gene ontology analyses: immune, cytoskeleton, glycolysis, transcription, mitochondria and oxidative phosphorylation, lysosome, splicing, exosome and two functional nodes related to cell adhesion (Figure 4).

Functional node activities were then calculated as the mean of the expression of those proteins related to the biological function of each functional node. Comparing the two molecular groups, there were significant differences in glycolysis, immune response, extracellular matrix, exosomes, lysosomes, and cytoskeleton functional activities (Figure 5).

Proteins related with tumor relapse and disease-free survival signature

Next, proteins related to relapse and disease-free survival were identified and a prognostic signature was defined. Initially, twenty-nine out of 1,206 identified proteins were prioritized based on their association with relapse ( $p<0.01$, Table 2$)$.

These 29 proteins associated with relapse were then used to build a prognostic signature. This predictor split the patient cohort into low- and high-risk groups ( $p$-value $=0.0002$, Hazard ratio $[H R]=6.51,20-80 \%)$. The predictor was based on the expression of proteins NIPSNAP1 (NipSnap homolog 1) and RBM3 (RNA-binding protein 3) (Figure 6). The formula to calculate the prognostic index is $\sum w_{i} x_{i}-4.264$, where $\mathrm{PI}$ is the prognostic index, and $\mathrm{x}$ refers to protein abundances, $w$ to the weights of each protein and $i$ to the sample. A sample is being classified in the high-risk group when the prognostic index $(\mathrm{PI})$ is higher than -0.584 . Known characteristics of each protein are provided in Table 3.

Univariate and multivariate analysis of risk factors for tumor relapse are shown in Table 4. Tumor size, positive lymph nodes and the prognostic signature were significantly associated with an increased risk of relapse based on the univariate analysis. Multivariate statistical 
bioRxiv preprint doi: https://doi.org/10.1101/2020.09.21.306654; this version posted September 24, 2020. The copyright holder for this preprint

(which was not certified by peer review) is the author/funder. All rights reserved. No reuse allowed without permission.

Characterization of triple negative breast cancer by DIA

analysis showed that the prognostic signature was an independent prognostic factor for relapse.

\section{Discussion}

Breast cancer is the most frequent malignant tumor in women and among them, TNBC is associated with a worst prognosis. For this reason, most of patients with TNBC receive adjuvant or neoadjuvant chemotherapy, but it leads to overtreatment in some of them. Therefore, the identification of patients with low-risk of relapse would allow avoiding unnecessary treatments and toxicities. On the other hand, a better understanding of the underlying molecular biology could help to select those high-risk patients that could benefit from intensive follow-up and participation in clinical trials with new drugs. In this work, clinical and molecular features of a group of TNBC patients were analyzed.

Most of the patients included in this study presented grade III tumors, a size greater than $2 \mathrm{~cm}$, and lymph node involvement, similar characteristics to other TNBC patient series $(1,36,37)$. Forty-five percent of the patients included in this study presented a relapse (local or distant). The local relapse rate was $8 \%$, and the distant relapse rate $37 \%$. In a similar study that included 83 TNBC patients treated with anthracyclines, distant relapse rate was 34\% (36). In Dent et al., $34 \%$ of the patients experienced a distant relapse and $15 \%$, a local relapse (1). TNBC has a greater incidence of visceral metastases than estrogen-receptor positive tumors $(1,6-9,38)$, particularly at the CNS and lungs. In our cohort, CNS was the most frequent site of distant relapse ( $n=12,10 \%)$, followed by lung metastases $(n=10,8 \%)$. Therefore, our sample was representative of the TNBC population.

Proteomics provides direct information about biological processes. Many efforts have been devoted to identifying proteomics signatures with prognostic value $(15,36,39)$. Until now, proteomics based on mass-spectrometry has been the most used technique to identify therapeutic targets and prognostic biomarkers. However, despite the recent advances, only a 
Characterization of triple negative breast cancer by DIA

few biomarkers have been identified and proteomics technology still has limitations for clinical application. The standard in proteomics experiments used to be LC-MS/MS using datadependent acquisition (DDA) mode. Recently, data-independent acquisition methods have emerged, which enable the reproducible quantification and identification of proteins in large patient cohorts (40) with high accuracy and consistency(41).

A previous study using SWAT-MS in breast cancer samples established that TNBC was an heterogeneous group (22). In this study, fresh-frozen breast tissue samples were used to classify breast tumors in proteomics-based groups. A different study, which analyzed breast cancer cell lines of all subtypes and four TNBC tumor samples by LC-MS/MS, also established differences at protein level between breast cancer subtypes (42). Data obtained by our DIA experiments in breast cancer FFPE TNBC samples allowed us to divide patients with TNBC into two different groups (with 76 and 49 patients, respectively). Although no difference in survival appeared between these two groups, this molecular classification might provide patient stratification and be the basis for a targeted therapy for each one of these groups. The SAM found 439 proteins differentially expressed between these two molecular groups. Proteins were related to glycolysis, membrane, adhesion, mitochondria and translation. Molecular characterization of tumors is useful to define common biological alterations within subsets of patients that may become therapeutic targets. For example, SAM analysis showed that one of these differential processes is mitochondrial function. Metformin has an action on mitochondria and has been shown to affect cell viability in TNBC cell lines, so it could be useful in tumors that overexpress proteins related to mitochondria (43). Glycolysis was another relevant process, for which targeted drugs such as 2-D-deoxy-glucose are also available (44).

With the aim of studying protein relationships in TNBC, a PGM was built with the 1,206 protein abundances. This allowed us creating a graphical representation with ten functional nodes. There were differences in functional node activities between the two proteomics molecular 
Characterization of triple negative breast cancer by DIA

groups in glycolysis, immune response, extracellular matrix, exosomes, lysosomes, and cytoskeleton. The characterization of differences at immune level has acquired a great relevance with the advent of immunotherapy. Differences in the immune functional node could be related to immunotherapy response. Recent studies suggests some role of anti-PD1 therapy in TNBC (45). Therefore, it would be interesting to find a good biomarker in this scenario to select patients for immunotherapy. Strikingly, there were significant differences in glycolysis functional node between the two groups that also appeared in SAM analyses. This functional approach offers complementary information to conventional analyses.

Moreover, in this work we have achieved the identification of a prognostic predictor based on proteomics data in TNBC. Twenty-nine proteins were related with relapse and the analysis of these proteins allowed us to build a prognostic signature based on two proteins: RBM3 and NIPSNAP1. RBM3 was associated with a lower risk of relapse, and NIPSNAP1, with worse prognosis. This protein signature is simpler and better, based on the obtained HR, than the P5 protein signature presented in previous works (15).

RBM3 is a member of the cold-shock protein family that regulates mRNA metabolism and has pleiotropic effects in cellular stress and oncogenesis (46). RBM3 protein is rarely overexpressed in normal tissues, but it is overexpressed in some solid tumors and, in recent studies, its expression levels seem to be related to prognosis and cytostatic sensitivity. High levels of RBM3 are an independent prognostic factor for DFS and overall survival in breast cancer $(47,48)$, ovarian carcinoma (49), gastric cancer $(50)$, colon cancer $(51,52)$, prostate cancer (53), and melanoma (54). Our study confirms that RBM3 maintains its prognostic value in tumors with negative hormone receptors.

NIPSNAP1 is a protein usually expressed in CNS, liver and kidney. Its function is not clearly defined $(55,56)$. NIPSNAP1 is only expressed in neuronal tissues and it has been previously related to Alzheimer disease and phenylketonuria. Its association with cancer remains 
Characterization of triple negative breast cancer by DIA

undefined. However, the fact that in our study, which comprehends a cohort with a significant presence of CNS metastases, NIPSNAP1 expression was associated with high-risk of relapse, suggests that it deserves future studies.

Despite the interest of our results, this study does not come without some limitations. First, it is worth mentioning that this was a retrospective study, and some patients received chemotherapy combinations that differ from the current standard. Moreover, the prognostic signature defined for predicting the risk of relapse is still a candidate prognostic signature and it will need prospective independent validation before its potential clinical application.

Overall, data-independent acquisition mass-spectrometry (DIA-MS) has demonstrated its utility in molecular characterization of archived triple negative breast cancer (TNBC FFPE) samples. In this study, we established two different molecular groups in TNBC patients with differential abundance of proteins related to mitochondria, membrane, adhesion and translation. The use of probabilistic graphical models (PGM) allowed the study of differences in biological processes between groups of patients and also suggested some processes with different activity between the two molecular groups. These processes could be exploited in the future as potential new therapeutic targets. In addition, proteomics data analysis allowed us to build a prognostic signature in TNBC population based on RBM3 and NIPSNAP1 abundances and the relationship between RBM3 and low-risk of relapse previously shown in other studies was confirmed.

\section{Acknowledgements}

This work is supported by PI12/00444 from Instituto de Salud Carlos III, Spanish Economy and Competitiveness Ministry, Spain. The CRG/UPF Proteomics Unit is part of the Spanish Infrastructure for Omics Technologies (ICTS OmicsTech) and it is a member of the ProteoRed PRB3 consortium which is supported by grant PT17/0019 of the PE I+D+i 2013-2016 from the Instituto de Salud Carlos III (ISCIII) and ERDF. We acknowledge support from the Spanish 
Characterization of triple negative breast cancer by DIA

Ministry of Science, Innovation and Universities, “Centro de Excelencia Severo Ochoa 2013-

2017", SEV-2012-0208, and "Secretaria d'Universitats i Recerca del Departament d'Economia i

Coneixement de la Generalitat de Catalunya" (2017SGR595). This project has also received

funding from the European Union's Horizon 2020 research and innovation program under

grant agreement No 823839 (EPIC-XS). LT-F is supported by the Spanish Economy and

Competitiveness Ministry (DI-15-07614). GP-V and MIL-H is supported by the Consejería de

Educación, Juventud y Deporte of Comunidad de Madrid (IND2017/BMD7783). AZ-M is

supported by Consejería de Educación e Investigación de la Comunidad de Madrid

(IND2018/BMD-9262). EL-C is supported by the Spanish Economy and Competitiveness

Ministry (PTQ2018-009760). The sponsors were not involved in the study design, in data

collection and analysis, in the decision to publish or in the preparation of this manuscript.

\section{Data availability}

The raw proteomics data have been deposited to the PRIDE repository (57) with the dataset identifier PXD021491. 
bioRxiv preprint doi: https://doi.org/10.1101/2020.09.21.306654; this version posted September 24, 2020. The copyright holder for this preprint

(which was not certified by peer review) is the author/funder. All rights reserved. No reuse allowed without permission.

Characterization of triple negative breast cancer by DIA

\section{References}

1. Dent, R., Trudeau, M., Pritchard, K. I., Hanna, W. M., Kahn, H. K., Sawka, C. A., Lickley, L. A., Rawlinson, E., Sun, P., and Narod, S. A. (2007) Triple-negative breast cancer: clinical features and patterns of recurrence. Clin Cancer Res 13, 4429-4434

2. Liedtke, C., Mazouni, C., Hess, K. R., Andre, F., Tordai, A., Mejia, J. A., Symmans, W. F., Gonzalez-Angulo, A. M., Hennessy, B., Green, M., Cristofanilli, M., Hortobagyi, G. N., and Pusztai, L. (2008) Response to neoadjuvant therapy and long-term survival in patients with triple-negative breast cancer. J Clin Oncol 26, 1275-1281

3. Tischkowitz, M., Brunet, J. S., Bégin, L. R., Huntsman, D. G., Cheang, M. C., Akslen, L. A., Nielsen, T. O., and Foulkes, W. D. (2007) Use of immunohistochemical markers can refine prognosis in triple negative breast cancer. BMC Cancer 7, 134

4. Reddy, S. M., Barcenas, C. H., Sinha, A. K., Hsu, L., Moulder, S. L., Tripathy, D., Hortobagyi, G. N., and Valero, V. (2018) Long-term survival outcomes of triple-receptor negative breast cancer survivors who are disease free at 5 years and relationship with low hormone receptor positivity. Br J Cancer 118, 17-23

5. Smid, M., Wang, Y., Zhang, Y., Sieuwerts, A. M., Yu, J., Klijn, J. G., Foekens, J. A., and Martens, J. W. (2008) Subtypes of breast cancer show preferential site of relapse. Cancer Res 68, 3108-3114

6. Harrell, J. C., Prat, A., Parker, J. S., Fan, C., He, X., Carey, L., Anders, C., Ewend, M., and Perou, C. M. (2012) Genomic analysis identifies unique signatures predictive of brain, lung, and liver relapse. Breast Cancer Res Treat 132, 523-535

7. Kennecke, H., Yerushalmi, R., Woods, R., Cheang, M. C., Voduc, D., Speers, C. H., Nielsen, T. O., and Gelmon, K. (2010) Metastatic behavior of breast cancer subtypes. J Clin Oncol 28, 3271-3277

8. Rodríguez-Pinilla, S. M., Sarrió, D., Honrado, E., Hardisson, D., Calero, F., Benitez, J., and Palacios, J. (2006) Prognostic significance of basal-like phenotype and fascin expression in node-negative invasive breast carcinomas. Clin Cancer Res 12, 1533-1539

9. Lin, N. U., Vanderplas, A., Hughes, M. E., Theriault, R. L., Edge, S. B., Wong, Y. N., Blayney, D. W., Niland, J. C., Winer, E. P., and Weeks, J. C. (2012) Clinicopathologic features, patterns of recurrence, and survival among women with triple-negative breast cancer in the National Comprehensive Cancer Network. Cancer 118, 5463-5472

10. Lehmann, B. D., Jovanović, B., Chen, X., Estrada, M. V., Johnson, K. N., Shyr, Y., Moses, H. L., Sanders, M. E., and Pietenpol, J. A. (2016) Refinement of Triple-Negative Breast Cancer Molecular Subtypes: Implications for Neoadjuvant Chemotherapy Selection. PLoS One 11, e0157368

11. Lehmann, B. D., Bauer, J. A., Chen, X., Sanders, M. E., Chakravarthy, A. B., Shyr, Y., and Pietenpol, J. A. (2011) Identification of human triple-negative breast cancer subtypes and preclinical models for selection of targeted therapies. J Clin Invest 121, 2750-2767

12. Burstein, M. D., Tsimelzon, A., Poage, G. M., Covington, K. R., Contreras, A., Fuqua, S. A., Savage, M. I., Osborne, C. K., Hilsenbeck, S. G., Chang, J. C., Mills, G. B., Lau, C. C., and Brown, P. H. (2015) Comprehensive genomic analysis identifies novel subtypes and targets of triple-negative breast cancer. Clin Cancer Res 21, 1688-1698

13. Jézéquel, P., Loussouarn, D., Guérin-Charbonnel, C., Campion, L., Vanier, A., Gouraud, W., Lasla, H., Guette, C., Valo, I., Verrièle, V., and Campone, M. (2015) Gene-expression molecular subtyping of triple-negative breast cancer tumours: importance of immune response. Breast Cancer Res 17, 43

14. Masuda, H., Baggerly, K. A., Wang, Y., Zhang, Y., Gonzalez-Angulo, A. M., MericBernstam, F., Valero, V., Lehmann, B. D., Pietenpol, J. A., Hortobagyi, G. N., Symmans, W. F., and Ueno, N. T. (2013) Differential response to neoadjuvant chemotherapy among 7 triplenegative breast cancer molecular subtypes. Clin Cancer Res 19, 5533-5540 
bioRxiv preprint doi: https://doi.org/10.1101/2020.09.21.306654; this version posted September 24, 2020. The copyright holder for this preprint

(which was not certified by peer review) is the author/funder. All rights reserved. No reuse allowed without permission.

Characterization of triple negative breast cancer by DIA

15. Gámez-Pozo, A., Trilla-Fuertes, L., Prado-Vázquez, G., Chiva, C., López-Vacas, R., Nanni, P., Berges-Soria, J., Grossmann, J., Díaz-Almirón, M., Ciruelos, E., Sabidó, E., Espinosa, E., and Fresno Vara, J. (2017) Prediction of adjuvant chemotherapy response in triple negative breast cancer with discovery and targeted proteomics. PLoS One 12, e0178296

16. Gillet, L. C., Navarro, P., Tate, S., Röst, H., Selevsek, N., Reiter, L., Bonner, R., and Aebersold, R. (2012) Targeted data extraction of the MS/MS spectra generated by dataindependent acquisition: a new concept for consistent and accurate proteome analysis. $\mathrm{Mol}$ Cell Proteomics 11, 0111.016717

17. Bruderer, R., Muntel, J., Müller, S., Bernhardt, O. M., Gandhi, T., Cominetti, O., Macron, C., Carayol, J., Rinner, O., Astrup, A., Saris, W. H. M., Hager, J., Valsesia, A., Dayon, L., and Reiter, L. (2019) Analysis of 1508 Plasma Samples by Capillary-Flow Data-Independent Acquisition Profiles Proteomics of Weight Loss and Maintenance. Mol Cell Proteomics 18, 1242-1254

18. Egertson, J. D., Kuehn, A., Merrihew, G. E., Bateman, N. W., MacLean, B. X., Ting, Y. S., Canterbury, J. D., Marsh, D. M., Kellmann, M., Zabrouskov, V., Wu, C. C., and MacCoss, M. J.

(2013) Multiplexed MS/MS for improved data-independent acquisition. Nat Methods 10, 744746

19. Kiyonami, R., Senko, M., Zabrouskov, V., Hühmer, A., Egertson, J., Ting, S., and MacCoss, M. (2014) Large scale targeted protein quantification using WiSIM-DIA workflow on a orbitrap fusion tribrid mass spectrometer. Thermo Scientific Application Note 600

20. Borràs, E., and Sabidó, E. (2018) DIA+: A Data-Independent Acquisition Method Combining Multiple Precursor Charges to Improve Peptide Signal. Anal Chem 90, 12339-12341 21. Collins, B. C., Hunter, C. L., Liu, Y., Schilling, B., Rosenberger, G., Bader, S. L., Chan, D. W., Gibson, B. W., Gingras, A. C., Held, J. M., Hirayama-Kurogi, M., Hou, G., Krisp, C., Larsen, B., Lin, L., Liu, S., Molloy, M. P., Moritz, R. L., Ohtsuki, S., Schlapbach, R., Selevsek, N., Thomas, S. N., Tzeng, S. C., Zhang, H., and Aebersold, R. (2017) Multi-laboratory assessment of reproducibility, qualitative and quantitative performance of SWATH-mass spectrometry. Nat Commun 8, 291

22. Bouchal, P., Schubert, O. T., Faktor, J., Capkova, L., Imrichova, H., Zoufalova, K., Paralova, V., Hrstka, R., Liu, Y., Ebhardt, H. A., Budinska, E., Nenutil, R., and Aebersold, R. (2019) Breast Cancer Classification Based on Proteotypes Obtained by SWATH Mass Spectrometry. Cell Rep 28, 832-843.e837

23. Gámez-Pozo, A., Ferrer, N. I., Ciruelos, E., López-Vacas, R., Martínez, F. G., Espinosa, E., and Vara, J. (2013) Shotgun proteomics of archival triple-negative breast cancer samples. Proteomics Clin Appl 7, 283-291

24. Chiva, C., Olivella, R., Borràs, E., Espadas, G., Pastor, O., Solé, A., and Sabidó, E. (2018) QCloud: A cloud-based quality control system for mass spectrometry-based proteomics laboratories. PLoS One 13, e0189209

25. Tsou, C. C., Avtonomov, D., Larsen, B., Tucholska, M., Choi, H., Gingras, A. C., and Nesvizhskii, A. I. (2015) DIA-Umpire: comprehensive computational framework for dataindependent acquisition proteomics. Nat Methods 12, 258-264, 257 p following 264

26. Choi, M., Chang, C. Y., Clough, T., Broudy, D., Killeen, T., MacLean, B., and Vitek, O. (2014) MSstats: an R package for statistical analysis of quantitative mass spectrometry-based proteomic experiments. Bioinformatics 30, 2524-2526

27. Saeed, A. I., Sharov, V., White, J., Li, J., Liang, W., Bhagabati, N., Braisted, J., Klapa, M., Currier, T., Thiagarajan, M., Sturn, A., Snuffin, M., Rezantsev, A., Popov, D., Ryltsov, A., Kostukovich, E., Borisovsky, I., Liu, Z., Vinsavich, A., Trush, V., and Quackenbush, J. (2003) TM4: a free, open-source system for microarray data management and analysis. Biotechniques 34 , 374-378

28. Tusher, V. G., Tibshirani, R., and Chu, G. (2001) Significance analysis of microarrays applied to the ionizing radiation response. Proc Natl Acad Sci U S A 98, 5116-5121 
bioRxiv preprint doi: https://doi.org/10.1101/2020.09.21.306654; this version posted September 24, 2020. The copyright holder for this preprint

(which was not certified by peer review) is the author/funder. All rights reserved. No reuse allowed without permission.

Characterization of triple negative breast cancer by DIA

29. Abreu, G., Edwards, D., and Labouriau, R. (2010) High-Dimensional Graphical Model Search with the gRapHD R Package pp. 1-18, Journal of Statistical Software

30. Lauritzen, S. (1996) Graphical Models, Oxford,UK.: Oxford University Press

31. Huang, d. W., Sherman, B. T., and Lempicki, R. A. (2009) Systematic and integrative analysis of large gene lists using DAVID bioinformatics resources. Nat Protoc 4, 44-57

32. Gámez-Pozo, A., Trilla-Fuertes, L., Berges-Soria, J., Selevsek, N., López-Vacas, R., DíazAlmirón, M., Nanni, P., Arevalillo, J. M., Navarro, H., Grossmann, J., Gayá Moreno, F., Gómez Rioja, R., Prado-Vázquez, G., Zapater-Moros, A., Main, P., Feliú, J., Martínez del Prado, P., Zamora, P., Ciruelos, E., Espinosa, E., and Fresno Vara, J. Á. (2017) Functional proteomics outlines the complexity of breast cancer molecular subtypes. Scientific Reports 7, 10100

33. Gámez-Pozo, A., Berges-Soria, J., Arevalillo, J. M., Nanni, P., López-Vacas, R., Navarro, H., Grossmann, J., Castaneda, C., Main, P., Díaz-Almirón, M., Espinosa, E., Ciruelos, E., and Fresno-Vara, J. A. (2015) Combined label-free quantitative proteomics and microRNA expression analysis of breast cancer unravel molecular differences with clinical implications. pp. 2243-2253, Cancer Res

34. de Velasco, G., Trilla-Fuertes, L., Gamez-Pozo, A., Urbanowicz, M., Ruiz-Ares, G., Sepúlveda, J. M., Prado-Vazquez, G., Arevalillo, J. M., Zapater-Moros, A., Navarro, H., LopezVacas, R., Manneh, R., Otero, I., Villacampa, F., Paramio, J. M., Vara, J. A. F., and Castellano, D. (2017) Urothelial cancer proteomics provides both prognostic and functional information. Sci Rep 7, 15819

35. Simon, R. (2005) Roadmap for developing and validating therapeutically relevant genomic classifiers. J Clin Oncol 23, 7332-7341

36. Campone, M., Valo, I., Jézéquel, P., Moreau, M., Boissard, A., Campion, L., Loussouarn, D., Verriele, V., Coqueret, O., and Guette, C. (2015) Prediction of Recurrence and Survival for Triple-Negative Breast Cancer (TNBC) by a Protein Signature in Tissue Samples. Mol Cell Proteomics 14, 2936-2946

37. Bauer, K. R., Brown, M., Cress, R. D., Parise, C. A., and Caggiano, V. (2007) Descriptive analysis of estrogen receptor (ER)-negative, progesterone receptor (PR)-negative, and HER2negative invasive breast cancer, the so-called triple-negative phenotype: a population-based study from the California cancer Registry. Cancer 109, 1721-1728

38. Dawood, S., Broglio, K., Esteva, F. J., Yang, W., Kau, S. W., Islam, R., Albarracin, C., Yu, T. K., Green, M., Hortobagyi, G. N., and Gonzalez-Angulo, A. M. (2009) Survival among women with triple receptor-negative breast cancer and brain metastases. Ann Oncol 20, 621-627

39. Liu, N. Q., Stingl, C., Look, M. P., Smid, M., Braakman, R. B., De Marchi, T., Sieuwerts, A. M., Span, P. N., Sweep, F. C., Linderholm, B. K., Mangia, A., Paradiso, A., Dirix, L. Y., Van Laere, S. J., Luider, T. M., Martens, J. W., Foekens, J. A., and Umar, A. (2014) Comparative proteome analysis revealing an 11-protein signature for aggressive triple-negative breast cancer. J Natl Cancer Inst 106, djt376

40. Hu, A., Noble, W. S., and Wolf-Yadlin, A. (2016) Technical advances in proteomics: new developments in data-independent acquisition. F1000Res 5

41. Ludwig, C., Gillet, L., Rosenberger, G., Amon, S., Collins, B. C., and Aebersold, R. (2018) Data-independent acquisition-based SWATH-MS for quantitative proteomics: a tutorial. $\mathrm{Mol}$ Syst Biol 14, e8126

42. Lawrence, R. T., Perez, E. M., Hernández, D., Miller, C. P., Haas, K. M., Irie, H. Y., Lee, S. I., Blau, C. A., and Villén, J. (2015) The Proteomic Landscape of Triple-Negative Breast Cancer. Cell Rep 11, 990

43. Trilla-Fuertes, L., Gámez-Pozo, A., Arevalillo, J. M., Díaz-Almirón, M., Prado-Vázquez, G., Zapater-Moros, A., Navarro, H., Aras-López, R., Dapía, I., López-Vacas, R., Nanni, P., Llorente-Armijo, S., Arias, P., Borobia, A. M., Maín, P., Feliú, J., Espinosa, E., and Fresno Vara, J. (2018) Molecular characterization of breast cancer cell response to metabolic drugs.

Oncotarget 9, 9645-9660 
bioRxiv preprint doi: https://doi.org/10.1101/2020.09.21.306654; this version posted September 24, 2020. The copyright holder for this preprint

(which was not certified by peer review) is the author/funder. All rights reserved. No reuse allowed without permission.

Characterization of triple negative breast cancer by DIA

44. Akkiprik, M., Feng, Y., Wang, H., Chen, K., Hu, L., Sahin, A., Krishnamurthy, S., Ozer, A., Hao, X., and Zhang, W. (2008) Multifunctional roles of insulin-like growth factor binding protein 5 in breast cancer. Breast Cancer Res 10, 212

45. Schmid, P., Chui, S. Y., and Emens, L. A. (2019) Atezolizumab and Nab-Paclitaxel in Advanced Triple-Negative Breast Cancer. Reply. N Engl J Med 380, 987-988

46. Pilotte, J., Kiosses, W., Chan, S. W., Makarenkova, H. P., Dupont-Versteegden, E., and Vanderklish, P. W. (2018) Morphoregulatory functions of the RNA-binding motif protein 3 in cell spreading, polarity and migration. Sci Rep 8, 7367

47. Jögi, A., Brennan, D. J., Rydén, L., Magnusson, K., Fernö, M., Stål, O., Borgquist, S., Uhlen, M., Landberg, G., Påhlman, S., Pontén, F., and Jirström, K. (2009) Nuclear expression of the RNA-binding protein RBM3 is associated with an improved clinical outcome in breast cancer. Mod Pathol 22, 1564-1574

48. Kang, S. H., Cho, J., Jeong, H., and Kwon, S. Y. (2018) High RNA-binding Motif Protein 3 Expression Is Associated with Improved Clinical Outcomes in Invasive Breast Cancer. J Breast Cancer 21, 288-296

49. Ehlén, A., Brennan, D. J., Nodin, B., O'Connor, D. P., Eberhard, J., Alvarado-Kristensson, M., Jeffrey, I. B., Manjer, J., Brändstedt, J., Uhlén, M., Pontén, F., and Jirström, K. (2010) Expression of the RNA-binding protein RBM3 is associated with a favourable prognosis and cisplatin sensitivity in epithelial ovarian cancer. J Transl Med 8, 78

50. Ye, F., Jin, P., Cai, X., Cai, P., and Cai, H. (2017) High RNA-Binding Motif Protein 3 (RBM3) Expression is Independently Associated with Prolonged Overall Survival in IntestinalType Gastric Cancer. Med Sci Monit 23, 6033-6041

51. Jang, H. H., Lee, H. N., Kim, S. Y., Hong, S., and Lee, W. S. (2017) Expression of RNAbinding Motif Protein 3 (Anticancer Res 37, 1779-1785

52. Siesing, C., Sorbye, H., Dragomir, A., Pfeiffer, P., Qvortrup, C., Pontén, F., Jirström, K., Glimelius, B., and Eberhard, J. (2017) High RBM3 expression is associated with an improved survival and oxaliplatin response in patients with metastatic colorectal cancer. PLoS One 12, e0182512

53. Jonsson, L., Gaber, A., Ulmert, D., Uhlén, M., Bjartell, A., and Jirström, K. (2011) High RBM3 expression in prostate cancer independently predicts a reduced risk of biochemical recurrence and disease progression. Diagn Pathol 6, 91

54. Jonsson, L., Bergman, J., Nodin, B., Manjer, J., Pontén, F., Uhlén, M., and Jirström, K. (2011) Low RBM3 protein expression correlates with tumour progression and poor prognosis in malignant melanoma: an analysis of 215 cases from the Malmö Diet and Cancer Study. J Transl Med 9, 114

55. Tummala, H., Li, X., and Homayouni, R. (2010) Interaction of a novel mitochondrial protein, 4-nitrophenylphosphatase domain and non-neuronal SNAP25-like protein homolog 1 (NIPSNAP1), with the amyloid precursor protein family. Eur J Neurosci 31, 1926-1934

56. Nautiyal, M., Sweatt, A. J., MacKenzie, J. A., Mark Payne, R., Szucs, S., Matalon, R., Wallin, R., and Hutson, S. M. (2010) Neuronal localization of the mitochondrial protein NIPSNAP1 in rat nervous system. Eur J Neurosci 32, 560-569

57. Perez-Riverol, Y., Csordas, A., Bai, J., Bernal-Llinares, M., Hewapathirana, S., Kundu, D. J., Inuganti, A., Griss, J., Mayer, G., Eisenacher, M., Pérez, E., Uszkoreit, J., Pfeuffer, J., Sachsenberg, T., Yilmaz, S., Tiwary, S., Cox, J., Audain, E., Walzer, M., Jarnuczak, A. F., Ternent, T., Brazma, A., and Vizcaíno, J. A. (2019) The PRIDE database and related tools and resources in 2019: improving support for quantification data. Nucleic Acids Res 47, D442-D450 
bioRxiv preprint doi: https://doi.org/10.1101/2020.09.21.306654; this version posted September 24, 2020. The copyright holder for this preprint (which was not certified by peer review) is the author/funder. All rights reserved. No reuse allowed without permission.

Characterization of triple negative breast cancer by DIA

Tables and legends

Table 1: Patients' characteristics.

\begin{tabular}{|c|c|c|}
\hline & Total $(n=125)$ & Percentage (\%) \\
\hline $\begin{array}{l}\text { Age at diagnosis. Median } \\
\text { (range) }\end{array}$ & $56.8(24.7-85.2)$ & \\
\hline \multicolumn{3}{|l|}{ Tumor size } \\
\hline T1 & 44 & $35.2 \%$ \\
\hline $\mathrm{T} 2$ & 67 & $53.6 \%$ \\
\hline T3 & 7 & $5.6 \%$ \\
\hline $\mathrm{T} 4$ & 7 & $5.6 \%$ \\
\hline \multicolumn{3}{|l|}{ Lymph node status } \\
\hline NO & 63 & $50.4 \%$ \\
\hline N1 & 39 & $31.2 \%$ \\
\hline N2 & 8 & $6.4 \%$ \\
\hline N3 & 14 & $11.2 \%$ \\
\hline Unknown & 1 & $0.8 \%$ \\
\hline \multicolumn{3}{|l|}{ Grade } \\
\hline 1 & 3 & $2.4 \%$ \\
\hline 2 & 17 & $13.6 \%$ \\
\hline 3 & 103 & $82.4 \%$ \\
\hline Unknown & 2 & $1.6 \%$ \\
\hline \multicolumn{3}{|l|}{ TNM stage } \\
\hline 1 & 31 & $24.8 \%$ \\
\hline IIA & 39 & $31.2 \%$ \\
\hline IIB & 25 & $20.0 \%$ \\
\hline IIIA & 10 & $8.0 \%$ \\
\hline IIIB & 5 & $4.0 \%$ \\
\hline IIIC & 14 & $11.2 \%$ \\
\hline Unknown & 1 & $0.8 \%$ \\
\hline \multicolumn{3}{|l|}{ Treatment } \\
\hline Anthracyclines and taxanes & 31 & $24.8 \%$ \\
\hline Anthracyclines & 48 & $38.4 \%$ \\
\hline Taxanes & 1 & $0.8 \%$ \\
\hline $\begin{array}{r}\text { Neither anthracyclines nor } \\
\text { taxanes }\end{array}$ & 33 & $26.4 \%$ \\
\hline None & 7 & $5.6 \%$ \\
\hline Unknown & 5 & $4.0 \%$ \\
\hline
\end{tabular}

Table 2: Proteins associated with relapse $(p<0.01)$.

\begin{tabular}{ccccccc}
\hline order & $\begin{array}{c}\text { Parametric } \\
\text { p-value }\end{array}$ & FDR & $\begin{array}{c}\text { Hazard } \\
\text { Ratio }\end{array}$ & $\begin{array}{c}\text { SD of log } \\
\text { intensities }\end{array}$ & Protein ID & Gene ID \\
\hline 1 & $1.68 \mathrm{E}-05$ & 0.0202 & 1.609 & 1.232 & Q9BPW8|NIPS1_HUMAN & NIPSNAP1 \\
2 & $5.12 \mathrm{E}-05$ & 0.0308 & 1.414 & 1.691 & Q00610|CLH1_HUMAN & CLTC
\end{tabular}


Characterization of triple negative breast cancer by DIA

\begin{tabular}{|c|c|c|c|c|c|c|}
\hline 3 & 0.0001144 & 0.0459 & 0.862 & 2.651 & Q8NCX0|CC150_HUMAN & CCDC150 \\
\hline 4 & 0.0001758 & 0.0529 & 1.408 & 1.55 & Q14204|DYHC1_HUMAN & DYNC1H1 \\
\hline 5 & 0.0007118 & 0.142 & 0.71 & 1.372 & Q5SSJ5|HP1B3_HUMAN & HP1BP3 \\
\hline 6 & 0.0007492 & 0.142 & 1.31 & 1.73 & Q12931|TRAP1_HUMAN & TRAP1 \\
\hline 7 & 0.000827 & 0.142 & 0.689 & 1.285 & Q92522|H1X_HUMAN & H1FX \\
\hline 8 & 0.0013019 & 0.18 & 1.262 & 1.871 & Q01082|SPTB2_HUMAN & SPTBN1 \\
\hline 9 & 0.0013466 & 0.18 & 0.838 & 1.76 & $\begin{array}{l}\text { P55795|HNRH2_HUMAN; } \\
\text { P52597|HNRPF_HUMAN; } \\
\text { P31943|HNRH1_HUMAN }\end{array}$ & $\begin{array}{l}\text { HNRNPH2 } \\
\text { HNRNPF } \\
\text { HNRNPH1 }\end{array}$ \\
\hline 10 & 0.0016436 & 0.191 & 1.302 & 1.697 & P38646|GRP75_HUMAN & HSPA9 \\
\hline 11 & 0.0017466 & 0.191 & 0.69 & 1.21 & $\begin{array}{l}\text { P16403|H12_HUMAN; } \\
\text { P22492|H1T_HUMAN; } \\
\text { P16402|H13_HUMAN; } \\
\text { Q02539|H11_HUMAN }\end{array}$ & $\begin{array}{l}\text { HIST1H1C } \\
\text { HIST1H1T } \\
\text { HIST1H1D } \\
\text { HIST1H1A }\end{array}$ \\
\hline 12 & 0.0019854 & 0.192 & 0.863 & 1.893 & $\begin{array}{l}\text { Q8N257|H2B3B_HUMAN; } \\
\text { Q6DN03|H2B2C_HUMAN }\end{array}$ & $\begin{array}{l}\text { HIST3H2BB } \\
\text { HIST2H2BC }\end{array}$ \\
\hline 13 & 0.0020735 & 0.192 & 0.787 & 1.847 & P51608|MECP2_HUMAN & MECP2 \\
\hline 14 & 0.0036046 & 0.31 & 0.789 & 1.59 & P98179|RBM3_HUMAN & RBM3 \\
\hline 15 & 0.0047713 & 0.322 & 0.735 & 1.246 & P16401|H15_HUMAN & HIST1H1B \\
\hline 16 & 0.0050095 & 0.322 & 1.316 & 1.342 & O75323|NIPS2_HUMAN & NIPSNAP2 \\
\hline 17 & 0.0050886 & 0.322 & 0.778 & 1.524 & Q13151|ROA0_HUMAN & HNRNPAO \\
\hline 18 & 0.0052312 & 0.322 & 1.395 & 1.196 & P36957|ODO2_HUMAN & DLST \\
\hline 19 & 0.005341 & 0.322 & 0.776 & 1.418 & O75367|H2AY_HUMAN & H2AFY \\
\hline 20 & 0.0053512 & 0.322 & 0.83 & 1.696 & P35754|GLRX1_HUMAN & GLRX \\
\hline 21 & 0.0056807 & 0.324 & 0.847 & 2.466 & Q8WU39|MZB1_HUMAN & MZB1 \\
\hline 22 & 0.0061962 & 0.324 & 0.768 & 1.277 & Q9UKM9|RALY_HUMAN & RALY \\
\hline 23 & 0.0062543 & 0.324 & 0.861 & 2.343 & Q9Y5P6|GMPPB_HUMAN & GMPPB \\
\hline 24 & 0.0066871 & 0.324 & 1.306 & 1.579 & Q13011|ECH1_HUMAN & $\mathrm{ECH} 1$ \\
\hline 25 & 0.006735 & 0.324 & 1.226 & 1.85 & O43776|SYNC_HUMAN & NARS \\
\hline 26 & 0.0094255 & 0.399 & 1.275 & 1.461 & P55084|ECHB_HUMAN & HADHB \\
\hline 27 & 0.0094698 & 0.399 & 1.266 & 1.488 & O95831|AIFM1_HUMAN & AIFM1 \\
\hline 28 & 0.0095317 & 0.399 & 0.887 & 2.806 & Q9NYL4|FKB11_HUMAN & FKBP11 \\
\hline 29 & 0.009621 & 0.399 & 0.732 & 1.215 & Q07666|KHDR1_HUMAN & KHDRBS1 \\
\hline
\end{tabular}

Table 3: Characteristics of the proteins identified by the predictor. 
bioRxiv preprint doi: https://doi.org/10.1101/2020.09.21.306654; this version posted September 24,2020 . The copyright holder for this preprint (which was not certified by peer review) is the author/funder. All rights reserved. No reuse allowed without permission.

Characterization of triple negative breast cancer by DIA

\begin{tabular}{|c|c|c|c|c|}
\hline Gene ID & Protein name & Uniprot ID & Molecular function & $\begin{array}{c}\text { Subcellular } \\
\text { location }\end{array}$ \\
\hline NIPSNAP1 & $\begin{array}{l}\text { Protein NipSnap } \\
\text { homolog } 1\end{array}$ & $\begin{array}{l}\text { Q9BPW8| } \\
\text { NIPS1_HUMAN }\end{array}$ & - Neurotransmitter binding. & Mitochondria \\
\hline RBM3 & $\begin{array}{l}\text { RNA-binding } \\
\text { protein } 3\end{array}$ & $\begin{array}{l}\text { P98179' } \\
\text { RBM3_HUMAN }\end{array}$ & $\begin{array}{l}\text { - RNAm 3'-UTR binding. } \\
\text { - Poli(U) RNA binding. } \\
\text { - Ribosomal junction of large subunits } \\
\text { - RNA binding. } \\
\text { - RNAr binding of small ribosomal } \\
\text { subunit. } \\
\text {-Translation repressor activity. }\end{array}$ & Nucleus \\
\hline
\end{tabular}

Table 4. Risk factors associated with tumor relapse. $\mathrm{HR}=$ hazard ratio; $\mathrm{Cl}=$ confidence Interval;

$P=p$-value.

\begin{tabular}{|l|c|c|c|c|}
\hline \multirow{2}{*}{} & \multicolumn{2}{|c|}{ Univariate Analysis } & \multicolumn{2}{c|}{ Multivariate Analysis } \\
\cline { 2 - 5 } & $H R(95 \% \mathrm{Cl})$ & $P$ & $H R(95 \% \mathrm{Cl})$ & $P$ \\
\hline Grade & $10.31(0.01-10401.00)$ & 0.509 & --- & --- \\
\hline Tumor size $(T)$ & $1.92(1.43-2.56)$ & $<0.001$ & $1.59(1.14-2.22)$ & 0.007 \\
\hline Nodal status $(\mathrm{N})$ & $1.83(1.45-2.30)$ & $<0.001$ & $1.47(1.14-1.88)$ & 0.003 \\
\hline Prognostic signature & $6.66(2.07-21.37)$ & 0.001 & $5.19(1.19-16.94)$ & 0.006 \\
\hline
\end{tabular}

Figures and legends

Figure 1: Time of relapse (months since surgery of the primary tumor to tumor relapse).

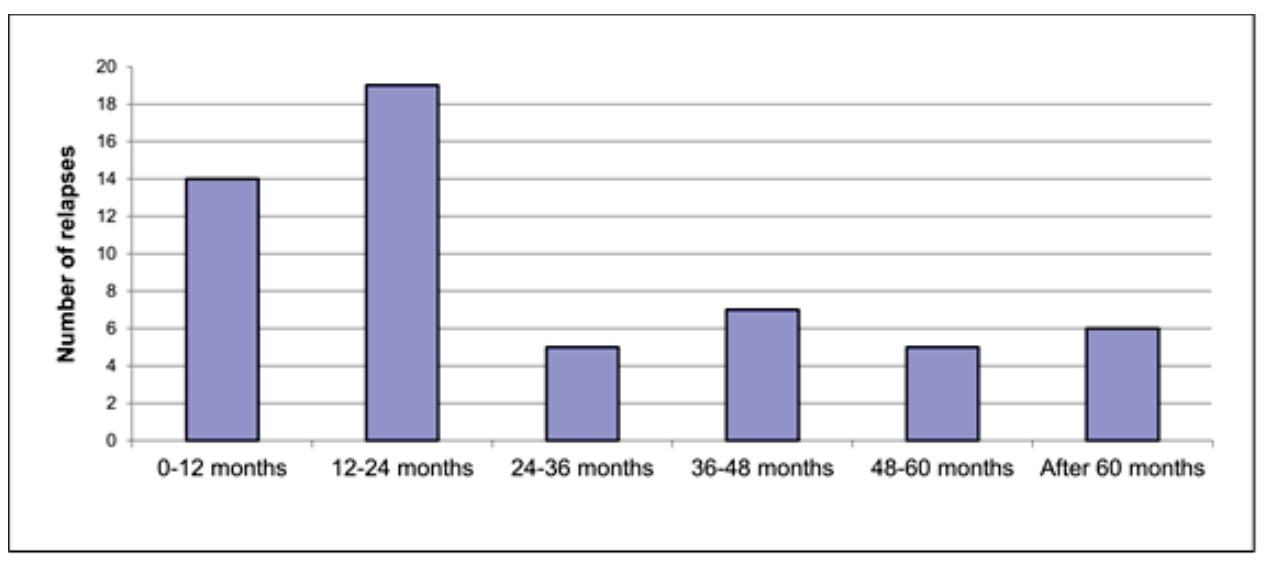

Figure 2: Number of proteins identified by sample using DIA+. 
bioRxiv preprint doi: https://doi.org/10.1101/2020.09.21.306654; this version posted September 24,2020 . The copyright holder for this preprint (which was not certified by peer review) is the author/funder. All rights reserved. No reuse allowed without permission.

Characterization of triple negative breast cancer by DIA

Number of identified proteins per sample

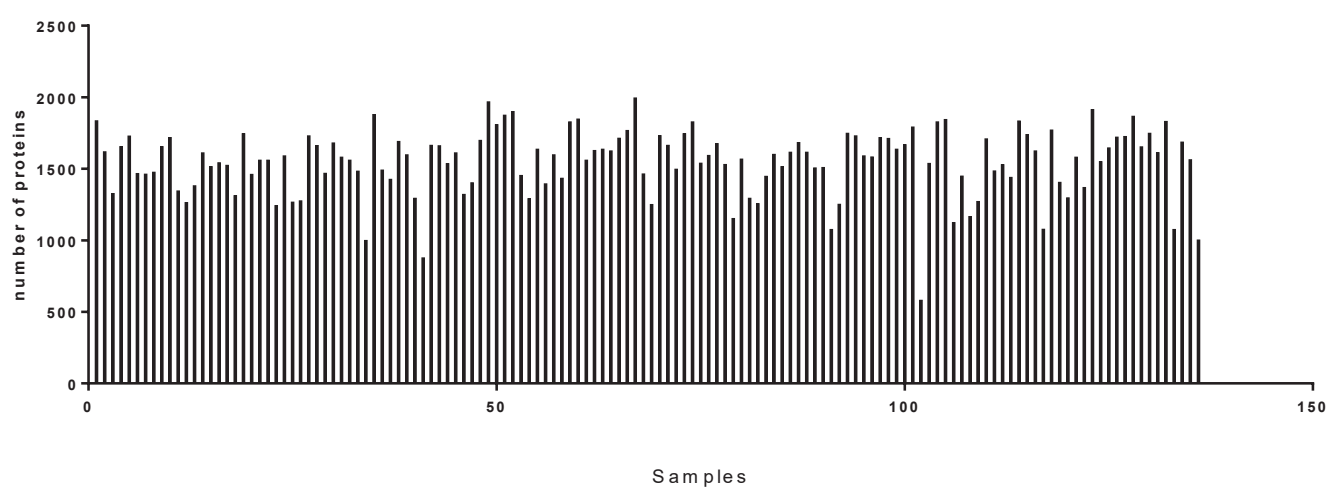

Figure 3: SAM between the two groups defined by $\mathrm{HCL}$. G1= Group 1; G2= Group 2. Green= underexpressed, Red= overexpressed.

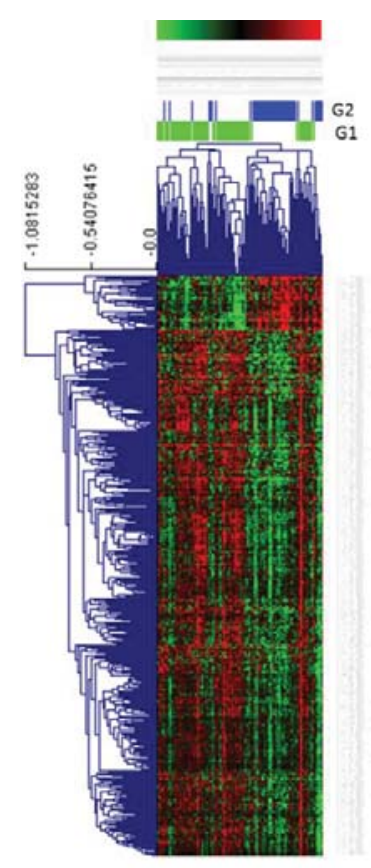

Figure 4: The probabilistic graphical model (PGM) functionally characterized built using the expression of the 1,206 identified proteins. 
bioRxiv preprint doi: https://doi.org/10.1101/2020.09.21.306654; this version posted September 24,2020 . The copyright holder for this preprint (which was not certified by peer review) is the author/funder. All rights reserved. No reuse allowed without permission.

Characterization of triple negative breast cancer by DIA

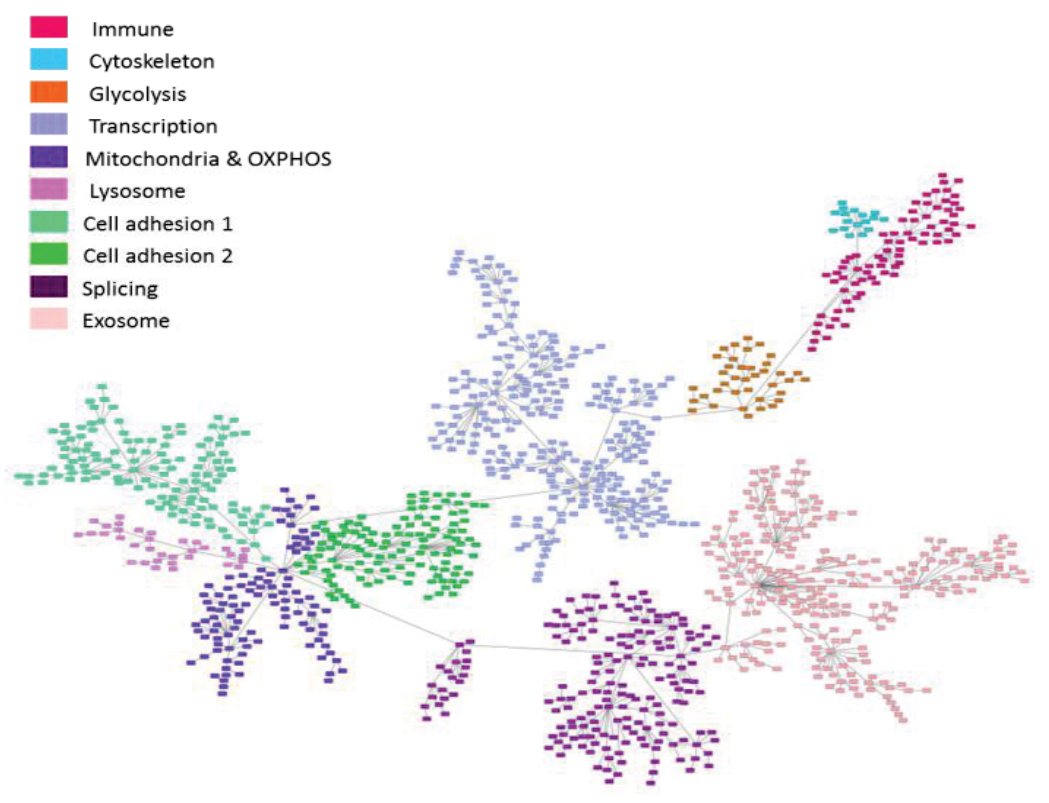

Figure 5: Functional node activities calculated for each molecular group. G1= group 1, G2=

group 2. * $\mathrm{p} \leq 0.05, * * \mathrm{p} \leq 0.01, * * * \mathrm{p} \leq 0.001, * * * * \mathrm{p} \leq 0.0001$.
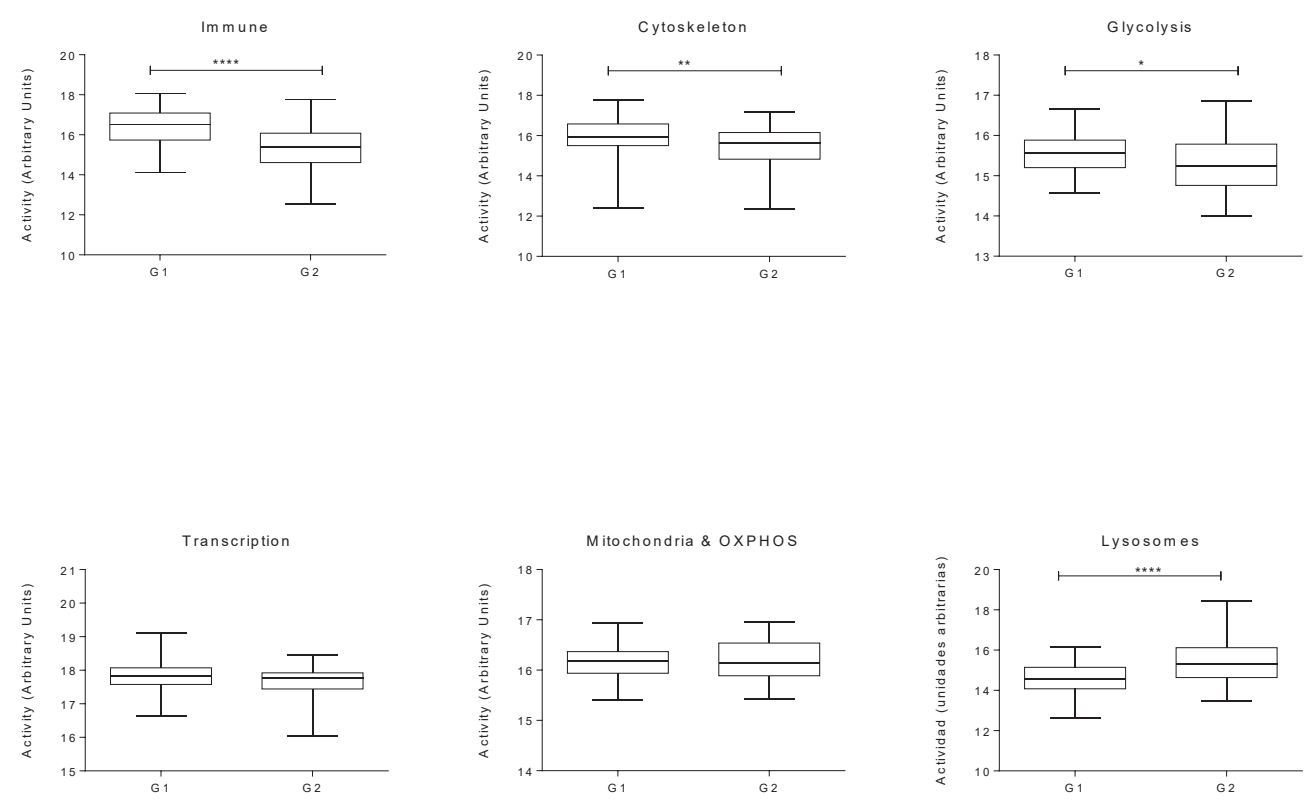
bioRxiv preprint doi: https://doi.org/10.1101/2020.09.21.306654; this version posted September 24, 2020. The copyright holder for this preprint (which was not certified by peer review) is the author/funder. All rights reserved. No reuse allowed without permission.

\section{Characterization of triple negative breast cancer by DIA}
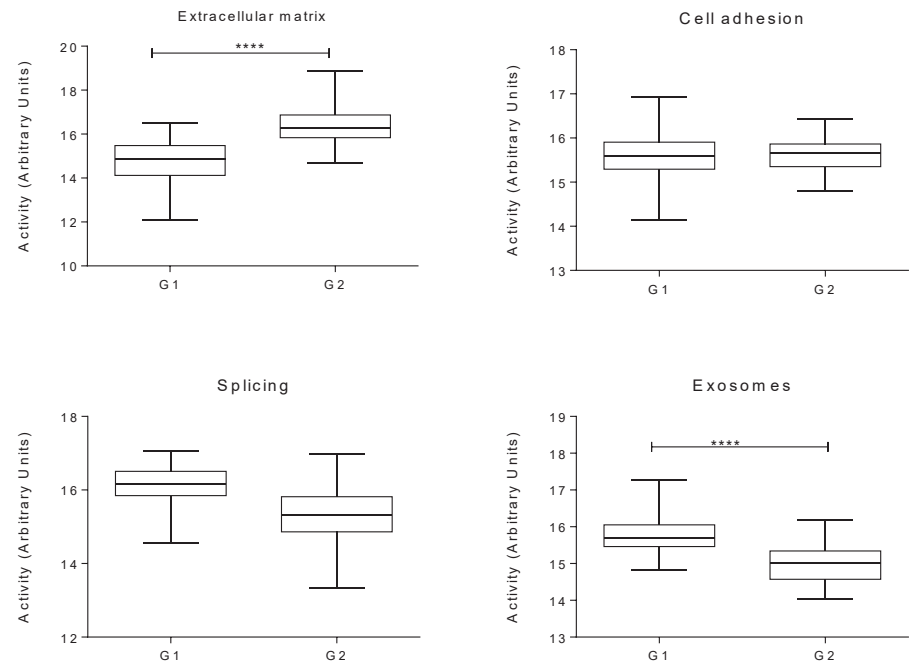

Figure 6: Predictor of relapse in TNBC based on the expression of NIPSNAP1 and RBM3. DFS = disease-free survival.

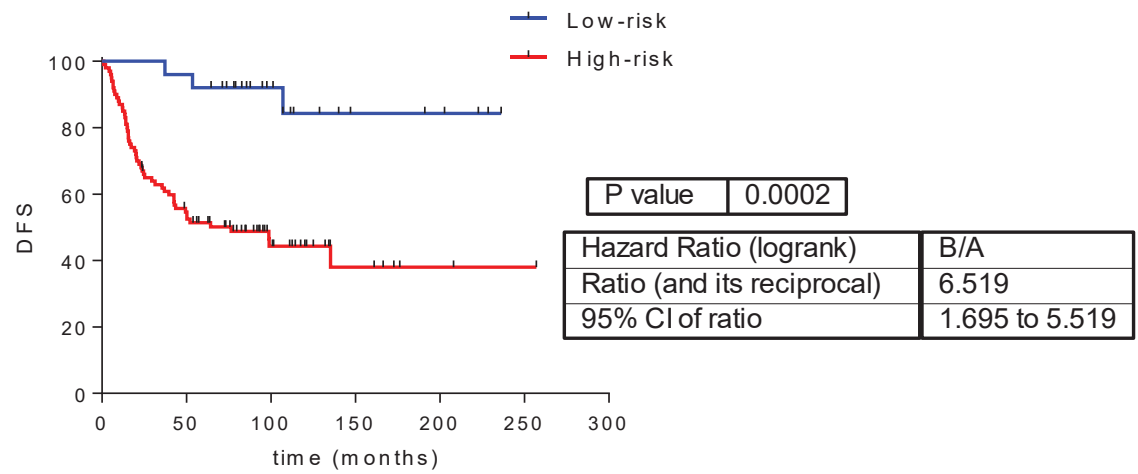

